\title{
RYEGRASS ENDOPHYTE INFECTION AFFECTS ARGENTINE STEM WEEVIL ADULT BEHAVIOUR AND SUSCEPTIBILITY TO PARASITISM
}

\author{
P.J. GERARD \\ AgResearch, Ruakura Research Centre, Private Bag 3123, Hamilton
}

\begin{abstract}
Pot experiments were undertaken to investigate whether Argentine stem weevil Listronotus bonariensis adults placed on endophyteinfected or endophyte-free perennial ryegrass (Lolium perenne) exhibited behaviour differences that may lead to differing susceptibility to attack by the endoparasitoid Microctonus hyperodae. There was no difference $(\mathrm{P}>0.05)$ in the behaviour of weevils on pots of Nui ryegrass infected with either the wildtype endophyte Neotyphodium lolii or AR1, a $N$. lolii selection high in peramine but low in other key alkaloids. Although adults were offered no choice, over $60 \%$ of the adults were found off endophyte-infected plants during the observation period. Weevils on high endophyte plants were found to spend less time in positions highly favourable for parasitoid oviposition (e.g. feeding $\mathrm{P}<0.001)$ and more time in unfavourable positions (e.g. crouching $\mathrm{P}<0.01)$ than found on nil endophyte plants. The presence of parasitoids decreased the level of weevil feeding $(\mathrm{P}<0.001)$. These differing behavioural responses to endophyte explain an observed inverse linear relationship between peramine and parasitism in the field.
\end{abstract}

Keywords: Listronotus bonariensis, Microctonus hyperodae, Neotyphodium lolii.

\section{INTRODUCTION}

The impact of Argentine stem weevil (ASW) (Listronotus bonariensis) on the pastoral industry has been lessened through the successful combination of plant resistance and biological control. Resistance is conferred by the fungal endophyte Neotyphodium lolii (Prestidge et al. 1982) and biological control using the endoparasitoid Microctonus hyperodae (Goldson et al. 1994). Research has shown there are interactions between $N$. lolii infected perennial ryegrass (Lolium perenne) and M. hyperodae. Barker and Addison (1996) demonstrated that N. lolii-infected ryegrass retarded $M$. hyperodae larval development in the host compared with uninfected ryegrass. Barker and Addison (1997) subsequently found that although $N$. lolii infection levels did not affect the efficacy of parasitism of naïve $M$. hyperodae, parasitoids with prior experience of hosts feeding on a particular grass had greater success in parasitising hosts on that grass. Recent field studies by Goldsonet al. (2000) have found a significant tritrophic interaction whereby percent parasitism was inversely related to levels of peramine, the antifeedant alkaloid on which the resistance is based (Rowan and Gaynor 1985). The most likely explanation was that parasitoids were less successful in finding and attacking prey on high endophyte plots (Goldson et al. 2000).

This paper reports the results of a study investigating the behaviour of ASW adults placed on endophyte-infected or endophyte-free ryegrass, and whether behavioural differences result in differing susceptibility to parasitoid attack. 


\section{METHODS}

Plants of perennial ryegrass cv. Nui containing nil endophyte, wild-type $N$. lolii or the AgResearch novel N. lolii endophyte AR1, were established in individual pots (95 $\mathrm{mm} \times 80 \mathrm{~mm}$ maximum diameter) filled to $20 \mathrm{~mm}$ from the top with potting mix. The pots were maintained in a screen house until each had at least five tillers. An epidermal strip of leaf sheath was taken from each plant, stained with analine blue and examined under a microscope to confirm the presence of endophyte. Before use, test plants were trimmed to $100 \mathrm{~mm}$ in height, desiccated sheath material was removed from tillers and the pots were topped with $10 \mathrm{~mm}$ of fine light-coloured sand to improve detection of weevils.

\section{Experiment 1 (April 1999)}

Experiment 1 was conducted indoors during the evening to optimise both weevil feeding and parasitoid oviposition behaviour. A single plant of each ryegrass line was placed in a large glass beaker so that no leaf tissue was in contact with any surface. ASW adults, from a site near Te Kuiti at which M. hyperodae has yet to establish, were starved for $24 \mathrm{~h}$ before use. Twenty weevils taken from the pool of starved weevils were placed on each pot. The beakers were covered with cling film to prevent weevil escape and left in the dark for $30 \mathrm{~min}$. Weevil position was thereafter assessed at approximately $15 \mathrm{~min}$ intervals over the following $2.5 \mathrm{~h}$. During assessment, only sufficient light was used to enable determination of weevil positions. The weevils were assessed as feeding (positioned head down and abdomen high), crouching, moving on grass, on pot or off pot. When the experiment was completed, the adults were returned to the pool.

This process was carried out on six consecutive evenings. Each batch of three plants was used on two consecutive evenings. Plants were placed in a random order each evening so that position would not influence observations.

\section{Experiment 2 (March 2000)}

ASW adults were collected from a site near Invermay at which Microtonus hyperodae has yet to establish. $M$. hyperodae adults were supplied from a rearing programme at AgResearch, Lincoln, and were fed a diluted honey solution daily.

Two plants with nil endophyte and two with wild-type $N$. lolii were placed individually in large glass beakers. Ten weevils were introduced onto each plant, and two or three parasitoids into the beaker of one of each pair of plants. This process was repeated on 8 evenings. Weevils exposed to parasitoids were discarded after use. Otherwise, the experimental method and assessments were identical to Trial 1.

\section{Analysis}

An analysis of variance was carried out on the data. In both experiments, not all weevils inside the test container were visible at each observation. Therefore the results are expressed as percentages of total weevils visible, rather than total weevils introduced.

\section{Experiment 1}

\section{RESULTS}

Endophyte-infection caused a marked effect on ASW adult behaviour (Table 1). Whereas $60 \%$ of weevils enclosed with an endophyte-free ryegrass plant were observed on the foliage, only around half this number were found on the foliage of AR1 and wild endophyte-infected plants $(\mathrm{P}<0.001)$. Of the weevils observed on the foliage, five times more weevils were feeding $(\mathrm{P}<0.001)$ and about half as many were crouching $(\mathrm{P}<0.01)$ on the endophyte-free plants compared with the endophyte-infected plants. Visual observations suggested that weevils enclosed on the endophyte-infected plants were more mobile. However, although higher numbers were found moving on the foliage, and on and or off the pot, only the latter observation was statistically significant $(\mathrm{P}<0.05)$. No differences in behaviour $(\mathrm{P}>0.05)$ were observed between weevils enclosed on plants infected with the wildtype or AR1 endophytes. 
TABLE 1: The relative numbers of ASW adults in various positions or exhibiting various behaviours when placed on endophyte-infected (AR1 and E+) and endophyte-free (E-) ryegrass.

\begin{tabular}{|c|c|c|c|c|}
\hline \multicolumn{5}{|c|}{ Mean $\%$ weevils/observation } \\
\hline Weevil position & AR 1 & $\mathrm{E}+$ & E- & Significance $^{1}$ \\
\hline \multicolumn{5}{|l|}{ Site observed } \\
\hline on foliage & 36 & 29 & 60 & $* * *$ \\
\hline on pot & 31 & 29 & 17 & ns \\
\hline off pot & 33 & 42 & 23 & $*$ \\
\hline \multicolumn{5}{|c|}{ Activity on foliage } \\
\hline feeding & 11 & 13 & 59 & $* * *$ \\
\hline crouching & 53 & 52 & 22 & $* *$ \\
\hline moving & 38 & 41 & 26 & $\mathrm{~ns}$ \\
\hline
\end{tabular}

$1 * \mathrm{P}<0.05, * * \mathrm{P}<0.01, * * * \mathrm{P}<0.001$.

\section{Experiment 2}

As in Experiment 1, more weevils $(\mathrm{P}<0.01)$ were found on the foliage and feeding $(\mathrm{P}<0.001)$ when enclosed with endophyte-free plants, than when placed with endophyteinfected plants (Table 2). Less adults were observed to be actively moving on foliage of endophyte-free plants than on those with endophyte $(\mathrm{P}<0.05)$.

Weevil activity was clearly influenced by parasitoid activity $(\mathrm{P}<0.05)$. Overall, the presence of parasitoids reduced the percentage of adults found on the foliage $(\mathrm{P}<0.05)$, and the level of feeding $(\mathrm{P}<0.001)$. Weevils tended to be more mobile $(\mathrm{P}>0.05)$ in the presence of parasitoids. The weevil behaviour fluctuated in response to the intensity of searching behaviour during a single evening. For example, at one observation time, when three aggressive parasitoids were active, no weevils could be observed. Often only the weevils in the vicinity of a parasitoid showed evasive rapid walking behaviour. Successful oviposition by parasitoids appeared most prevalent when there was only one parasitoid active in the test container and weevils were settled.

TABLE 2: The relative numbers of ASW adults (\% of those observed) in various positions or exhibiting various behaviours on ryegrass with or without endophyte infection and in the presence or absence of M. hyperodae adults.

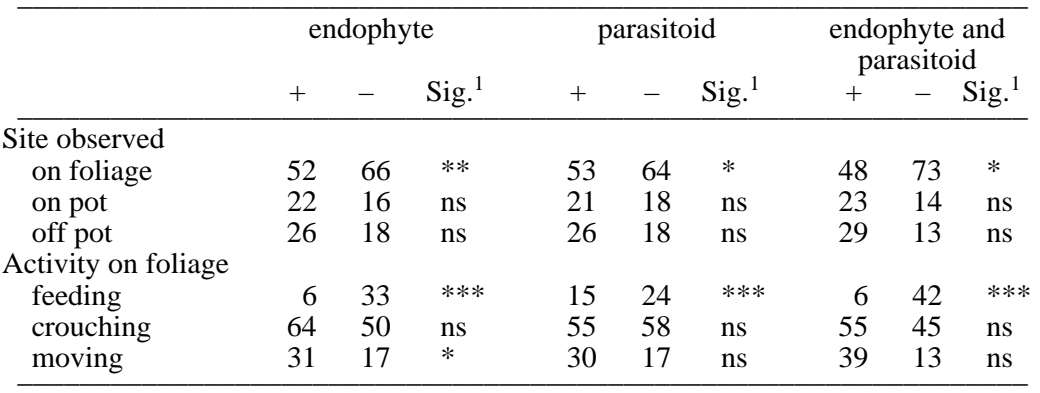

$1 * \mathrm{P}<0.05, * * \mathrm{P}<0.01, * * * \mathrm{P}<0.001$.

\section{DISCUSSION}

The results from these experiments confirm both that ASW adult feeding activity is greatly reduced in the presence of $N$. lolii (Prestige et al. 1991 and references therein) and that adult motility is increased as suggested by Barker and Addison (1997). The 
adult behavioural responses to endophyte are likely to be induced by the same endophyte alkaloids that reduced feeding damage in previous studies, namely peramine (Rowan and Gaynor 1985) and ergotamine (Popay et al. 1990). Behaviour of adults was not different on pots of ryegrass infected with the wildtype endophyte or AR1, an endophyte high in peramine but low in other key alkaloids. Therefore it appears that peramine alone is sufficient to induce significant changes in pattern of adult weevil behaviour.

ASW adults are most susceptible to parasitism when they are feeding, and least when they are inactive or moving (Phillips 1995). These experiments showed that around $90 \%$ of adults on the infected grasses were in positions unfavourable for parasitoid oviposition. This behavioural response by the weevils is likely to have given rise to the highly significant inverse linear effect of peramine on levels of parasitism found by Goldson et al. (2000).

ASW adult feeding activity was reduced in the presence of parasitoids. Observations suggest that when the ratio of parasitoids to weevil adults is high, parasitoids would be less successful in attack, not only through intraspecific competition, but also because of the high level of evasive behaviours induced in the weevil population.

\section{ACKNOWLEDGEMENTS}

Rory Logan and Simon Kelly for collection of insects; Mark McNeill, Paul Addison, Alison Popay and Steve Goldson for helpful advice; Catherine Cameron for statistical analyses; the Foundation for Research, Science and Technology for financial support.

\section{REFERENCES}

Barker, G.M. and Addison, P.J., 1996. Influence of clavicipitaceous endophyte infection in ryegrass on development of the parasitoid Microctonus hyperodae Loan (Hymenoptera: Braconidae) in Listronotus bonariensis (Kuschel) (Coleoptera: Curculionidae). Biol. Cont. 7: 281-287.

Barker, G.M. and Addison, P.J., 1997. Clavicipitaceous endophytic infection in ryegrass influences attack rate of the parasitoid Microctonus hyperodae (Hymenoptera: Braconidae, Euphorinae) in Listronotus bonariensis (Coleoptera: Curculionidae). Environ. Ent. 26: 416-420.

Goldson, S.L., Barker, G.M., Barratt, B.I.P. and Barlow, N.D., 1994. Progress in the biological control of Argentine stem weevil and comment on its potential.Proc. N.Z. Grasslands. Ass. 56: 39-42.

Goldson, S.L., Proffitt, J.R., Fletcher, L.R. and Baird, D.B., 2000. Multitrophic interaction between the ryegrass Lolium perenne, its endophyte Neotyphodium lolii, the weevil pest Listronotus bonariensis, and its parasitoid Microctonus hyperodae. N.Z. J. Agric. Res. (in press).

Popay, A.J., Prestidge, R.A., Rowan, D.D. and Dymock, J.J., 1990. The role of Acremonium lolii mycotoxins in insect resistance of perennial ryegrass (Lolium perenne). Proc. Int. Conf. Acremonium/Grass interactions: 44-49

Phillips, C.B., 1995. Intraspecific variation in Microctonus hyperodae and $M$. aethiopoides (Hymenoptera: Braconidae); significance for their use as biological control agents. Unpublished $\mathrm{PhD}$ thesis, Lincoln University, Lincoln, New Zealand. 167 pp.

Prestidge, R.A., Pottinger, R.P. and Barker, G.M., 1982. An association of Lolium endophyte with ryegrass resistance to Argentine stem weevil. Proc. 35th N.Z. Weed and Pest Control Conf. 119-122.

Prestidge, R.A., Barker, G.M. and Pottinger, R.P., 1991. Towards sustainable controls of pasture pests: progress on control of Argentine stem weevil (Listronotus bonariensis (Kuschel)). Proc. N.Z. Grasslands Assoc. 53: 25-31.

Rowan, D.D. and Gaynor, D.L., 1985. Isolation of feeding deterrents against Argentine stem weevil from ryegrass infected with the endophyte Acremonium lolii. J. Chem. Ecol. 12: 647-658. 